\title{
The Adjustments Space-Temporary of the Capitalism and Their Incidence in the Territorial Reconfiguration of the Commune Three of the City of Villavicencio, Meta, Colombia
}

\author{
Wilmar Andrés Morales López ${ }^{1}$, Martha Elena Roa Rodríguez ${ }^{2}$, and Jimmy Alexander \\ Pineda $^{3}$ \\ ${ }^{1}$ Principal investigator, Corporación Universitaria Minuto de Dios, Colombia \\ ${ }^{2}$ Coinvestigator, Corporación Universitaria Minuto de Dios, Colombia \\ ${ }^{3}$ Coinvestigator, Corporación Universitaria Minuto de Dios, Colombia
}

\begin{abstract}
.
This article questions the local impacts of the temporal-space adjustments of the capitalism in a global way. Its main objetctive is to interpret the effects of the informal and illicit economy (main local impacts) in the territory covered by the commune three from the city of Villavicencio, Meta, Colombia, in the XXI century. The interpretative process is structured in three moments. The first one aimed to do a contextualization of the transformations in the territory of the Colombian Orinoquía, the second one tended to identify the impacts of those territory transformations in the city of Villavicencio and finally it was done an interpretative work of the impacts of the informal and illicit economy from the perspective of the informal workers and university students who are residents in the commune three. The investigation work was conceived from an interpretative focus, methodologically it was opted an ethnographic and historical design which was complemented with the application of the SENSEMAKER software of qualitative research. It is concluded that the informal and illicit economy of the territory covered by the commune three provide the guidelines of socialization and culturalization through which a significance is achieved that incise in the semantic field of the spatiality, to the point of giving exclusion or inclusion indications to the social groups that have some relation with that territory.
\end{abstract}

Keywords: Capitalism, temporal-space adjustments, illicit and informal economy, commune three, Villavicencio, Meta, Colombia. 


\section{Introduction}

What is sustained in this text is the result of the second year of investigation of the proposal "Territory reconfiguration through violence social practices in the intermediate cities with high homicidal violence rates in the context of demobilization of illegal armed groups". ${ }^{1}$

One of the conclusions that was reached in the first year of investigation was to establish that the commune three of the cityof Villavicencio is one of the more affected in statistical terms by the phenomen of the homicidal violence associated to the organized crime, which economic activity is fundamentally the drug traffic under the mode of micro-trafficking.

It was pointed out, besides this, that in the context of the mentioned commune, although there are criminal groups characterized by the relations of kinship and friendship where the value of trust is fundamental, these groups are linked with a transactions network of the illicit economy way more wide, this means, with the regional and global chain of value of the cocaine, in this case, the trust value scarce and is replaced by the streamlined violence, an specific case is the homicide understood as a violence social practice. This way the regional dynamic of the armed conflict and the illicit economy influence in the behaviour of the homicide violence in the commune three.

After this first stage of investigation, where the criteria were argued to choose an urban context of the city of Villavicencio where it could be evidenced the territorial reconfigurations through the violence social practices, it happens the question for the defined territory like economic space but also as semantic space, so that, a methodology of investigation was designed that based on a review of secondary sources that would allow understand the space transformations of the Colombian Orinoquía in tune with the transformations of the capitalist economy of the beginning of the XXI century, for later, inquire from the perspective of one part of its inhabitants (university and informal sellers residents of the commune 3, about their ways to define and live the urban space related with the informal and illicit economy. To achieve the above, an interpretative framework was proposed from the historic and ethnographic method.

The new History is born in 1929 with the school of Annáles in France (Lucien Febvre and Marc Bloch) and shows its first jobs in Colombia in the decade of the 70's years. This new way of making history rejects the episodic history and try to explain the past of each town. The history is conceived as colective memory and not like heritage of a few ones, the facts are understood in so far as refered to the human life in society. For the New History, making history is to know the present from the past and project to the future, is not talking about the past by the past, as it was done before. The facts must be explained and besides this, the used

${ }^{1}$ Is an investigative proposal projected to three years that is proposed from the investigacion program in Transiciones, Memorias y Violencias; this program is leaded by the Universidad Católica de Pereira, Risaralda, Colombia The investigation is developed in a parallel way in several intermediate cities, where each one of the universities that shape the program study the pertinent to a city; in the present case, the Corporación Universitaria Minuto de Dios Vicerrectoría Regional Orinoquía leads the analysis of the city of Villavicencio, Meta, Colombia. One of the results of the first year of investigation was the publication of the book Crimen $\begin{array}{lllll}\text { organizado } y & \text { violencia homicida ciudades intermedias }\end{array}$ http://repositorio.utp.edu.co/dspace/handle/11059/11591 
sources must be submitted to the critical analysis. In the investigation it must be kept in mind the temporality, this means, the short and long duration of the phenomena that are explained.

Equally, the new History is supported by other disciplines to explain the facts, for that end it uses the Anthropology, the Sociology, the Psicology, the Geography, the Economy, the Stadistic, the Linguistic and the Paleography (study of ancient writings). In the work of the undertaken investigation it was used one of the ways to collect information to make history: the oral.

For this case, as an accompaniment and theorical support, a detailed and bibliographic review was attended of scientific character over the particular. The oral history has presented great resistances between the historians since it is considered weak, marked by subjectivity of the respondents, by their capacity of remembering and for the starring role or anonymous of the respondent in the fact that is narrated.

For other researchers, the oral history is equally valid and shouldn't have so much respect for the written word, since the narration must be received with equal care and must be confronted. The oral narration is a useful method to collect information of not written facts, in [1], [2].

In summary, is in the colective lived history where it is configured and weaving a cultural identity, where a sense of belonging of the territory is generated and identifies a society in relation to another through a way of being or idiosyncrasy. In other words, is where a culture is configured.

In terms of space every historical fact has an specific place, a territory where it is developed. The ethnographic method is the way used for excellence is used by the anthropology in the investigation and this leads us relentlessly to the place of the events. Nowadays, other social sciences make use of this method, as it is the case of the Sociology, the History itself and some aspects of psychology.

To the extent that the diversity of cultural patterns of life in the world are the base of the work, the researcher must go to the field, to "observe the matter in the natural situation" [3]. To broach the subject about the perception of the regulated space in a large degree by the violent practices derived from the illicit economy in the commune three, it was applied the methodology defined by the software of investigation SENSEMAKER.

This software allows to analyze the way in that the participants interpret themselves the situations that tell, from the context of their daily lives. The software makes quantifiable the meanings of their feelings and motivations in common context, shared with others.

The work that is presented becomes on the foundation of the work of investigation proposed for the third year (2021) of the research where it is based this article. This third year of work seeks to make a case study in the commune three of the city of Villavicencio that allows to answer the questions that are implicit in the objective of characterizing the sub-field of the ilegal economies ( criminal markets, capital, groups, interests) linked to organized armed groups in the cities that are object of study in the transitional stages during the processes of negotiation and implementation of the peace agreement of the century XXI in Colombia. 
In general terms, this work could make evident that the urban space correspondent to the commune three is the result of a historic process that dating from the midcentury XX, context in which Colombia went through a process of economic and cultural transformation at the rate in which the political and economic control imposed it, of the new hegemonic economy of the world, the United States and the the role of the violence as desarticulating of the peasant culture and its forms of tenure and rural land uses.

These dynamics started in the decade of 1950, they have another chapter in the years 80 's $\mathrm{y}$ 90's of the XX century where the capitalism it's transformed given its crises of overaccumulation and its strategies to solve them ( the accumulation by dispossesion). Undoubtedly the regional spaces and inside of these the rural and urban zones that become in the epicenter of the consequences more notorious in the regional and urban space of this readjustment : The accumulation of lands by dispossesion, the forced displacement as a engine of the rural and urban migrations and finally the informal economy and the illicit economy as structuring aspects of the daily life in the commune three.

\section{Body of paper}

\subsection{Introducction}

The present study it was done as an input that allows to understand the processes of territorial reconfiguration of the city of Villavicencio, Meta, Colombia. The region of Los Llanos Orientales of the cited country was one of the most affected given the implementation in the territory of the strategies of the capitalism to face its crisis of over-accumulation to the end of the XX century. It is held that this spacial transformation of the Llanos Orientales incised at the same time in the spacial logics of one of the contexts more conflictive of the city of Villavicencio, Meta, Colombia : the commune 3. With this we want to point out the local effects of the economic globalization processes, in this case, the main effects about the commune 3 were the consolidation of the informal economy and the illicit economy.

In this context of global and local economic transformation is where it can be understood the homicidal violence and its relation with the organized crime, aspects already analized by [4] But also to understand from the perspective of its inhabitants, how the informal and illicit economy give the guideliness of significance of the urban space addresed in the present investigative proposal. For the above, the question that encouraged this text was Which ones have been the effects in the territory understood by the commune three from Villavicencio of the adjustment processes of the global economy to the end of the $\mathrm{XX}$ century and the beginning of the XXI century.

To account the territorial transformation of the commune 3 from the city of Villavicencio, it is indispensable to understand the relation that this transformation save with the dynamics of the economic globalization that, without doubt, at the same time generated a process of territorial transformation of the Colombian high plain that is the regional context whre it is located the cited city. If the question is for the territory and its transformations, it is necessary to make clear in the beginning that is understood by globalization and its relation with the local.

In 2004, Silva de Sousa [5] in his analysis of the organized crime networks in Río de Janeiro, defines the economic globalization as a historic process which intensity reaches to 
impact in the localities and points out the much more marked way in where these ones are redefined in relation with the global order.

Even though, is pertinent to link to this definition of globalization, the lecture that David Harvey [6] makes of the capitalism, specially of that one he defines like capitalism by dispossesion, since, describes key aspect to understand the territorial reconfiguration of what is denominated as Colombian high plain.

Et al. [6], define the accumulation by dispossesion like a centrl future of the capitalism to a global escale to the end of the XX century; proposes that it's given in answer to the profiling of Asia like a new center of global power. A key concept in this context is the one of adjustment temporal-space that makes reference to the way as historically the capital has answered to one of its central problems, on the one hand, the surplus of work and the surplus of capital, what [6] defines like crisis of over-accumulation.

The adjustments temporal-spaces of the capitalism seek to solve this crisis of over accumulation applying strategies that go from the investment of capital in projects of different draughts or public expense, going through the global establishment of new productive capacities grounded in the exploitation of work force and new raw materials in contexts that before were not found integrated in the circuits of the global capital or propose [6] a combination of both aspects.

In this point is important to ask about the opening process of the Llanos Orientales from Colombia to new markets, and to the positioning in the region of "new productive capacities" aligned with global demands of energy ( case of biofuels) demand of illicit drugs and of environment services. Finally, this section will establish until what point these new productive capacities have been made through what [6] propose as accumulation by dispossesion; the author shores this concept pointing out that inside this narrative of the capitalism there was a moment of originative accumulation (moment fundamentally violent) to whom happened the development of the wide accumulation of capital, through the exploitation of live labor in the production,

Withing the framework of development of democratic values like the peace, the property and the equality. The key point of the author's argument, is to point, based in the argumentation of Marx, that the trade liberalization will produce higher standards of social inequality, as wellas it would produce crisis of over accumulation and definitely would point that the accumulation by dispossesion is not an initial trait of the capitalism but one permanet characteristic.

The defined characteristic, is traceable along the history of Colombia, however, there are tow factors that start to be observed starting from the decade of 1990, context where Colombia guides its economy through the global transformations that in this matter will guide in consensus of Washington and that definitely are evident from the beginning of the decade of 2000; these two factors are the foreignization of the land and its accumulation.

The effects of these aspects about the territories were varied and converged with the specific dynamics of the Colombian armed conflict and the different types of criminal markets, among which the most relevant has been the drug traffiking. The consequences can be listed of this phenomenal convergence in the region of the Llanos Orientales, in the next : 
1. Redefinition of the territory from economic criteria 2. Convergence between accumulation by dispossesion (dispossession legal or ilegal) and accumulation of capital (concentration and change in the use of the land) 3. Forced displacement and vulnerable population concentration in capital cities 4 . Consolidation of criminal markets of different nature, among which the most outstanding has been the drug trafficking.

The aspects listed, synthesize the conclusions of the works of [7], [8], [9], [10]. In general terms, the investigative cited works touch the problem of the land in the Colombian high plain and propose a framework of conceptual interpretation from the global logics of the capitalism, very close, or even using the analysis proposed by [6], for example, [9] use the category of crisis of over-accumulation and from spatial redefinition ( adjustment space-temporal) of [6] to show the new territoriality of the Llanos Orientales produced by the economic positioning of the hydrocarbons, the chain of value of the coca, the agrofuels and their geostrategic position in the economic map. [7] builds a rigorous historic analysis, legal and conceptual about the concentration and foreignization of lands in Colombia, of this work stands out, its reference to the reading that makes [6] of the capitalism from his concept of accumulation by dispossesion, differently of [9] propose a concept of contextualized hoarding in the Colombian reality, where stands out the dispossesion as one of his central futures.

The dispossesion is one of the hoarding dimensions of lands, [7] points how in some countries of Latin America the hoarding is related with the dispossesion, the forced displacement and the reconcentration of the land, according to this source, the hoarding of lands in Colombia will be configured by the historic failure of the agrarian reform, the concentration, the population displacement and the dispossesion. In this way, [7] defines the hoarding of lands as an strategy of territorial control that determines the possesion, the use and the productivity of the rural ground in many cases through the systematic violation of human rights.

[8] y [10] make a reading the aspects cited in the context of Los Llanos Orientales, this lecture offers information and data that allow understand the dimension of what happened in this region in the last two decades. His contributions point that the second entry (the first entry was with the oil exploitation) of the region of los Llanos Orientales to the cycles of accumulation of capital, it was done for the enlargement of the agroindustry of the coca and of what is denominated like green energies, where withouth questioning the protagonism is for the oil palm cultivation. Stands out in this ambit the convience between legal and ilegal actors to carry out the territorial transformations, spatial necessaries (grounded in the dispossesion) to profile the region to the investment of local and foreign capital, the above is defined in terms of the role of the criminal capitalism in the processes of acummuation of capital [9] and the constitution of a legal dispossesion [8].

One of the effects more notorious that relate the regional realities with the ones from the city of Villavicencio, is the forced displacement, namely, it is proposed that this is the way how the dynamics of the space-temporal adjustments of the Colombian Orinoquía relates with the processes of urbanization and constitution of the space of the city of Villavicencio,Meta, since this city has been established like the main place of reception of displaced pupulation from los Llanos Orientales. It is argued that the violet conflict evidenced in the commune 3 and whose structuring phenomen is the illicit economy, is the expression and result of the historic space-temporal by what the region has gone through and which antecedent most 
notable is found in the process of rural urban migration that happened in the context of what in Colombia has been named as politic violence or the violence in capital letters [7].

Concludes [7] that in similar way to the years of the named two-party violence (period understood between 1948 and 1962 in Colombia where it was given a sharp process of accumulation of capital inside the country grounded in the violence and the expoliation of the peasantry), in the century XXI premieres in Colombia with a city which periphery is the main stage of the spontaneous settlements of forced inmigrants and points repeteadly that this process is also characteristic of urban spaces way smaller, including of course the middle city.

The author takes up the concept of urban popular colonization from Aprile-Gniset as a conceptual basis through which explains the spacial transformations of the cities that ares hosts of inmigrants. However, to these defining characteristics of the process of rural-urban migration it has to be added other factors that in the dawn of the XXI century make even more difficult the question, these factors have to see with : a) the processes of transformation of the economy in the context of the radicalization of the globalization where the accumulation by dispossesion is the characteristic aspect of the adjustments space-temporal of Los Llanos Orientales and b) the positioning of the agroindustry of the coca which also has its chapter in the urban drug traffick.

It is here where the exhibition core is located in this article, pointing out how the space changes of the Orinoquia are expressed in the city Villavicencio, Meta, this means, paraphrasing to [7] How the space changes are expressed in Villavicencio as a refuge city?

\subsection{Methods}

The methodological approach seeks to understand the logics about the space of the illicit and informal economy from the interpretation that from these realities make informal sellers and university students who are residents of the commune three from Villavicencio. The work started from a selection and observation process of the informal sellers (informal economy) around a commercial axis, primarily structured by its strategic position inside the capital of the Meta department : the downtown; at the same time other characteristic factors of this human group were kept in mind, like the density every time more increasing.

From these socio-economic actors and the attractive element of the variety of merchandise, food and services that offer the pedestrians. For the above motives, specifically it was chosen the sector that offers three sub-cores of concentration ; Villa Julia, la Plazoleta de los Libertadores and Paseo de los Centauros; and the Plaza de Las Banderas with its neighborhood nodes La Plazoleta de Los Estudiantes and the Avenida 40 in the sector of the typographies and the photocopies service. To support the interpretation of the mentioned socio cultural conglomerate it went to the analysis of antropologyc character, in special those who come from the urban Antropology, the Economic Antropology and the Regional Etnology. Similarly, the data bult with the community they had the origin in open interviews and for the pictures the permission was obtained by the protagonists, clarifying that all the material had as a destination for academic purposes and in no moment the personal data or other sensitive information will be revealed. 
The process of observation, investigation, compilation, ordering and systematization was done during 10 weeks, where the various informal economic agents were contacted both in day hours and evening hours, at the same time in business days and holidays. This way the etnographyc study was not limited to the commercial space pointed above, but it could extend to the places of residence of many of the people interviewed thanks to the participation and interest of Mr Orlando $\mathrm{H}$, veteran trader of the sector, who maitain strong social relationship with these informal economic agents.

This way some neighborhoods of the commune 3 were visited which after four decades of settlement caused by displacement due to the armed conflict and in the opinion of Oscar A, communitary instructor of theater in the zone ,also for the hits that life gives you“, he has seen the sucesive arrival of inhabitants that in poor condition and extreme need, configure for the eyes of the left Villavicencio what Ezra Park denominate like the colognes and the segregation aereas, this means ,guetos, where individuals of the same race and similar occupation live together and where it tends to preserve the intimacy and the solidarity of the local groups and neighbors" while.

With the rest of the municipality the physical and affective distances are reinforced mutually " at a level that, those colognes have their places of meeting to every kind of criminals" [11] that in the present moment of the commune 3 it is recognized like the enclave of the Triangulo del Mal, which epicenter is formed by the neighborhoods Lambada, Delicias y Brisas del Guatiquía" (Oscar A., personal communication, Villavicencio, april 2009). Agree to report for this report that the informal merchants interviewed affirmed living in the commune 3 because of the scarce of economic resources to live in other sector and for the relative proximity to the downtown where they hae their ,puestos“ on the street to work.

This first approach to the stages of the informal merchants can be focused in the study of the localities like defined centers with economic, politics, social and cultural leaderships, the protagonists keep a rural environment bound or expressed in their traditions and present this way a direct relation with one or antoher municipality where they come from. This way, these informal, local stages are the spaces too where the communities see each other and have the awareness of themselves and where the cultural diversity is recognized for the community, this last one is one of the main elements socio-cultural to keep in mind in the whole study. In this sense it was considered reasonable to address the factors that show conveniently the fundamental role that embodies for the socio cultural adaptations the family life; the territory as meaning space and the values transmission.

Relating to the techniques uses in the picking up of the orality some observations previously made by [12] were followed. It was focused in the observation fundamentally in the esencial moment of the information transfer from the actor to the researcher : the interview. The interview is similar to the social Antropology and the oral history. In the first one, however, the interview is overdetermined by the observation of the participant, than by its particular characteristics is a indirect method of research, this makes that the interview in the frame of the observation the participant find her/him self under minimums regarding the formalization.

In a complementary way the software of cualitative investigation SENSEMAKER was applied to a total of 71 university students from the city of Villavicencio who are residents in the commune three. With the above seeked to collect the interpretation that the students made 
of their own stories related with the general environment of his residence place. Therefore, the methodologic process estimated that ecah one of the participants downloades in each one of their computers or mobiles the APP SENSEMAKER. Once it was done this the APP made the times of instrument to collect stories. The instrument makes the participant enter in the app a story, for this case the next situation was used as a detonating : If you had to tell a story about the general environment from your neighborhood to a unknown person who wants to know ¿What story would you tell ?

Later the participant makes a process of interpretation of the micro-story through an abstract construction background that are connected with their feelings, lectures about the territory, the power among others. These abstract constructions take the shape of triads or dyads where the particpant place the answer through a dot that locates in the space that conforms the criteria that are part ot the triad or dyad.

\subsection{Results and Discussion}

2.3.1 The interpretation of the territory by part of university youngs residents in the commune 3 of the city of Villavicencio.

The applied work point out that between the perceptions more relevants that have the students that answered to the instrument is that their territory is going through criminal logic that regulate the dynamics of the sectors where they live, this explain, in a good way how the fear becomes in a feeling expressed mostly to define the places of residence of our students, this allows to understand that the narrated situations by the participants are defined like sad.

When observing carefully the question of the control of the territory, it calls deeply the attention that in the perception of the students that part of the control of this one is done by ilegal armed groups or the militar presence, this point highlights in the perception of the students that the civil and not armed organizations have little interference in the affairs that have to see with the territory. Also it was found that within the perception of the students, that the problems narrated in their different stories tend to be solved using own hand justice instead of going to the instances that the state has for this purpose.

Within the general characteristics of the 71 participants in the methodology SENSEMAKER it is found that $38 \%$ of the particpants has been lived for more thatn 10 years in the sector, while the $28 \%$ showed to be living in the sector between 1 to 4 years, the $22 \%$ between 5 and 10 years and the $11 \%$ manifested that has been living in the sector less than 1 year. In regard to the situaton narrated by each one of the particpants it was found that $37 \%$ of them manifested to feel vulnerable, while $28 \%$ manifested to feel protected, the $13 \%$ frustrated, the $6 \%$ with rage and $16 \%$ didn't answer. In regard to how they would define the their story it was found that $35 \%$ of the people defined their stories like sad, the $28 \%$ like terrifying, the $19 \%$ like impressive and $8 \%$ like happy, $10 \%$ of the people didn't answer this point.

In the item the story that tells has to be with, it was found that $47 \%$ of the people point out their stories had to see with street robberies, while $18 \%$ point out that their stories had to see with the durg traffick, $17 \%$ showed that their stories are related with the control of the territory, $5 \%$ of people raised that their story had to be with domestic violence, $4 \%$ was 


\section{$3^{\text {rd }}$ International Conference On Research In} HUMANITIES \& SOCIAL SCIENCES

Bullying and 9\% didn't answer this item. In relation with the item about the place of occurrence of the story it was found that $24 \%$ of the people point out that the story told happened in the street (secondary via) while $20 \%$ indicated that the situation happened in the avenue (main via), 17\% showed that the situation happened in a park while $15 \%$ showed that what was narrated happened in a bridge, $10 \%$ showed that the story happened in a sports field, $14 \%$ didn't answer this point.

About the regularity of occurrence of the narrated, $71 \%$ of the people manifested that is very frequent that the stories narrated happen, $14 \%$ pointed that the storieds told are rare and unique, $11 \%$ indicated that the stories that were narrated happen once in a while, $1 \%$ poses that they don't know and 3\% didn't answer this item. About the question : Do exist places in your neighborhood whre you can transit? it was found that $63 \%$ of the people showed that do exist places by where they can transit, 3\% didn't apply in this item. In regard to the item if answered YES in the previous point Why can't you transit? It was found that $48 \%$ of people pointed that the motive why tey can't transit is due to the robbery, $30 \%$ points that they can't transit because there is consumption of drugs, $10 \%$ raised that can't transit by certain places beacuse there is drug trafficking, $6 \%$ showed that they can't transit because there are fights between combos and gangs, finally, other $6 \%$ answered that the motive why they can't transit is because there are invisible boarders.

In one of the the applied triads it was asked for the control of the territory, in this point the people answered $36 \%$ that the Police had the control of the territory, same percentage $36 \%$ determined that the control was exercised by groups outside the law. It's interesting to observe the $1 \%$ that determined that the control of the territory was from the religious groups and nor armed civils, this shows the weakeness of the social organizations and the public beyond the police presence, $3 \%$ poses that the territory is controlled by groups outside the law.

And religious and civil groups that are not armed. The $9 \%$ that is in the middle can indicate that the control of territory is divided between the groups outside the law, the religious and civil groups that are not armed and the police. 


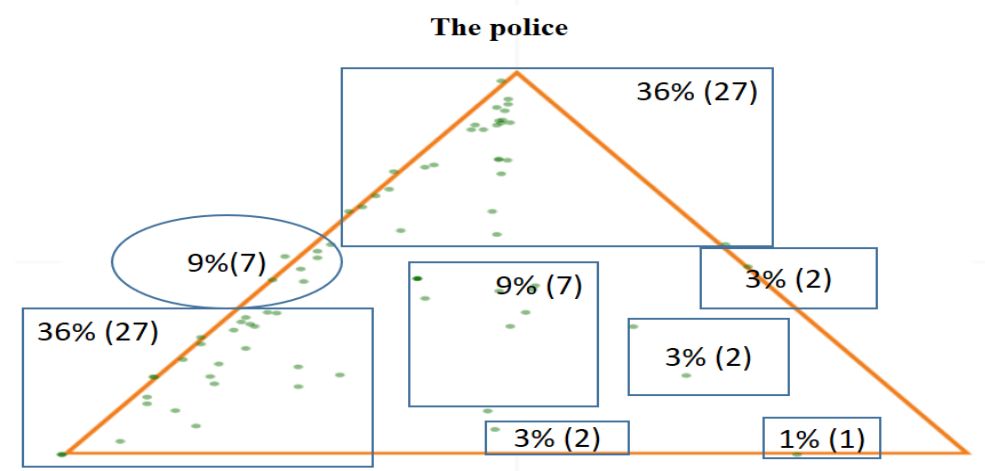

Groups outside the law

The religious groups and nor armed civils

\subsubsection{Considerations about the territory and the commercial informal scenes in the context of the informal economy}

In this context it was evidenced the way how the informal economy is the one that gives the guideline to understand the space as territory since this is one of the economic activities that give significance in the case concrete that is studied, the reflection focus in the space as category that acquires new meaning in the moment when is related with the human being. When that space turns significance, appears the notion of territory : „We see that all the other streets were busy and to not start a conflict we slowly started to be here in this passage, until the owners of the locals and the police and the passerbies got used to it" (el artesano del Paseo de Los Centauros). This way a human territory is a socialized and culturized space where you can achieve a significance that incides in the semantic field of the spatiality, at the point of giving exclusion or inclusion indications to the social groups that have any realation with that territory : „I am the unique who works here, to the sun and the water. Nobody else can do it. "I bought the position" to the guy who was before, no company hired me, drivers are the one who gives you one hundred, two hundred, pesitos everytime they cross and I tell you how long the other car passed“ („El Vecino“) Route caliper in the separator of Villa Julia, personal communication, Villavicencio, mayo 2019).

The territory is appropriate by individuals that interact and by social groups that generate multiple networks and solidarities, with the purpose of attending diverse vital needs:"We can change the day and the life to the people who pass by worried for going to their jobs, or to a medical consultation or in a rush to the bank. We want they to see that in this open space that they roam withouth watching there is a place for God and love to the neighbor" ( Protesstant 
missionary in the Main Park). The territory acquires singular characteristics in to the extent that who appropriate it, they do it from particular modes of life that make them different from the others : „here in the park people go by without looking at you and one feels that they despise you because of our job, they look at you as something minimum, nevertheless I fight to continue and go ahead and I identify myself with my place of work, I want it and I take care of it, this park for me makes part of my life" (The saleswoman of corn for the doves in the main park) As we see, the territory is the space or spaces that have significance for the rural or urban settler, farmer or citizen, man or woman, young or ancient, boy or adult. As José Luis García says, each human being acquire a complete knowledge of the spacial laws of his culture" [13].

\section{Conclusion}

The informal economy and the illicit are the aspects through which it can be understood the interaction between the constructions of the space and the territorial reconfigurations occured in the comuna 3 of the city of Villavicencio in the context of the adjustments space temporal occured in the region of Los Llanos Orientales given the crisis of overaccumulation of the capitalism at the end of the century XX. In this ambit excel the low capacity of the State of having the monopoly of the physical violence both in the region and the commune three, it can be argued that this last one is an expression to a scale of what happens in the region. The territory then like a semantic space it's been signified by the power that have on it illicit armed groups that regulate the criminal activities, but also the daily life of its inhabitants, pointing out the borders of a territory where they arrogate the possibility of deciding who gets in or out. Therefore, it's identified the limitation of the presence of the Colombian State, that generally express itself in militar presence, but not in initiatives that start from the socio-economic empowerment of the inhabitants of the commune.

The informal economy as a economic practice points out the meeting of a life characterized by the rural that before the fact of assuming (almost suddenly) the life in the city opts for colonize the urban space in an ilegal way. Therefore as in the Colombian violence context between 1948 and 1962 the peasant ancestors opted for colinizing zones that allow to broaden the agricultural boarder of the country, currently that colonization it's done in the urban space allowing enlarge the informal economy. In this case, like in the illicit economy, it was observed an appropriation of the territory that regulates who can or not exercise economic and informal activities, what was proposed above as inclusion and exclusion indicators to the social groups that have some relation with the territory.

Finally, this work becomes in an important antecedent to develop a case study in the commune three that allows to build the subfield of the ilegal economy and wonder specifically for the incidence of the processes of demobilization of the Autodefensas Unidas de Colombia (A.U.C) and the Fuerzas Armadas Revolucionarias de Colombia (FARC-EP) in this process of subfield structuring of the illicit economy in the commune three of Villavicencio at the begining of the XXI century. The above, will allow to consolidate scientific information about a specific context that allow to profile methodologies of analysis applicable to other contexts of the country. As well as the information about the perceptions, provisions and practices of the people embodying the processes described with the purpose of propose strategies that allow the building of a stable and lasting peace in the territories. 


\section{iorhs}

\section{$3^{\text {rd }}$ International Conference On Research In}

HUMANITIES \& SOCIAL SCIENCES

\section{References}

Thompson,P. (1998). La voz del pasado. La historia oral, Valencia: Artes Gráficas Soler.

Uribe M. T. (1993). Uribe, Los materiales de la memoria, Bogotá: Investigación cualitativa, 1993

Nanda, S. (1986). Antropología cultural. Adaptaciones socioculturales, Editoral Iberoaméricana.

Lenis,G; Morales,W. A y Casas,V. (2020). Crimen organizado y violencia homida en la ciudad de Villavicencio, Meta. En Crímen organizado y violenia homicida en ciudaes intermedias (pp 61-93), Pereira: Editorial Universidad Tecnológica de Pereira.

Silva de Sousa, R. (2004). «Narcotráfico y economía ilícita: las redes del crimen organizado en Río de Janeiro,» Revista méxicana de sociología, vol. 66, pp. 141192 , Enero.

Available:

http://www.scielo.org.mx/scielo.php?script=sci_arttext\&pid=S0188$\underline{25032004000100005}$

Harvey, D. (2005). «El "nuevo" imperialismo : acumulación por desposesión,» CLACSO, pp. 99-129. Available: http://biblioteca.clacso.org.ar/clacso/se/20130702120830/harvey.pdf

FAO. (2017).Concentración y extrangerización de tierras productivas en Colombia Marco conceptual, legal e instituional contribución a la aplicación de las Direectrices Voluntarias Sobre la Gobernanza Responsable de la Tenecia de la Tierra, Bogotá: FAO. Available: http://www.fao.org/3/a-i7843s.pdf

Mesa Corpartes Misereor. (2017.) Despojar y desplazar: Estrategia para el desarrollo de la Orinoquía, Bogotá: Impresol. Available: https://www.cinep.org.co/publicaciones/es/producto/despojar-y-desplazarestrategia-para-el-desarrollo-de-la-orinoquia/

Jiménez. C. (2012).«Valorización capitalista de la Orinoquia colombiana. División territorial del trabajo e inserción,» Ciencia Política, vol. 7, n 13, pp. 151-184. Available:

https://revistas.unal.edu.co/index.php/cienciapol/article/view/41514/43128

OXFAM. (2013). «Divide y comprarás: Una nueva forma de concentrar tierrras valdías en Colombia,» Oxfam GB, Reino Unido. Available: https://oi-files-d8-prod.s3.euwest-2.amazonaws.com/s3fs-public/file_attachments/rr-divide-and-purchase-landconcentration-colombia-270913-es_0.pdf

Ezra, R. (1999). La ciudad y otros ensayos de ecología humana, Barcelona: Ediciones del serbal.

Gonzáles, J. (1992). «Historia y antropología: De la teoría a la metódica pasando por las fuentes,» Gazeta de antropología, no 9, pp. 34-42, 1992.

J. L. García. (1976). Antropología del territorio, Madrid: Ediciones J.B. 